\title{
Dr. Antonio Marcos Machado Nunes - 1953* - 2005†
}

Faleceu no dia 15 de Abril de 2005 em Ribeirão Preto, após longa enfermidade, o Dr. Antonio Marcos Machado Nunes. Nascido em 16 de Junho de 1953, formou-se pela Faculdade de Ciências Medicas de Pouso Alegre - MG em 1978. Fez a Residência em Anestesiologia no Centro de Ensino e Treinamento da Santa Casa de Misericórdia de Ribeirão Preto nos anos de 1979 e 1980. Foi admitido no Serviço de Anestesiologia da Santa Casa de Misericórdia de Ribeirão Preto em 1981 e, após aprovação no Concurso do Titulo Superior em Anestesiologia da SBA, tornou-se seu Instrutor em 1983.

Participou como co-autor de 36 trabalhos científicos publicados na Revista Brasileira de Anestesiologia e em periódicos do exterior.

Freqüentou inúmeros Congressos e Jornadas de Anestesiologia. Exerceu as funções de Membro do ConseIho Técnico Deliberativo da Santa Casa de Misericórdia de Ribeirão Preto e, entre 2001 e 2004, foi Chefe do Serviço de Anestesiologia do mesmo Hospital.

Co-Responsável pelo CET-SBA da Santa Casa de Misericórdia de Ribeirão Preto desde 1990 até seu falecimento, destacou-se sempre pelo equilíbrio e pela maneira afável e simpática no trato com os colegas do Hospital, os Médicos Residentes, o pessoal paramédico e os muitos amigos que tinha na Sociedade Brasileira de Anestesiologia. Antonio Marcos deixa uma lacuna irreparável entre seus colegas do CET-SBA da Santa Casa de Misericórdia de Ribeirão Preto, e imensa saudade especialmente à dedicada esposa Maria Alice e aos dois filhos, Mariane e Guilherme, ambos cursando Medicina em Faculdades de Ribeirão Preto e do Rio de Janeiro, respectivamente.

Dr. José Roberto Nociti, TSA

Responsável pelo CET/SBA da Santa

Casa de Misericórdia de Ribeirão Preto, SP
After a long disease, Dr. Antonio Marcos Machado Nunes has passed away in Ribeirão Preto on April 15, 2005. He was born on June 16, 1953 and graduated by the School of Medical Sciences, Pouso Alegre - MG, in 1978. He was resident in Anesthesiology in the Teaching and Training Center, Santa Casa de Misericórdia, Ribeirão Preto, from 1979 to 1980. He was admitted to the Anesthesiology Department, Santa Casa de Misericórdia, Ribeirão Preto in 1981 and after approval in SBA's Superior Title in Anesthesiology test, he became its Professor in 1983.

Dr. Machado Nunes was co-author of 36 scientific studies published by the Brazilian Journal of Anesthesiology and by foreign publications.

He attended several Congresses and Journeys in Anesthesiology and was member of the Technical Deliberative Council, Santa Casa de Misericórdia, Ribeirão Preto, in addition to being Head of the Anesthesiology Department of this same Hospital from 2001 to 2004.

Co-responsible for the CET-SBA, Santa Casa de Misericórdia, Ribeirão Preto from 1990 until his passing away, he was always recognized by his common sense and the polite and nice way in dealing with colleagues, resident physicians, paramedical staff and the many friends he had in the Brazilian Society of Anesthesiology.

Antonio Marcos leaves an irretrievable gap among his colleagues from CET-SBA, Santa Casa de Misericórdia, Ribeirão Preto, and a deep ache, specially to his dedicated wife Maria Alice and his two children, Mariane and Guilherme, both studying medicine in Schools in Ribeirão Preto and Rio de Janeiro, respectively.

José Roberto Nociti, TSA, M.D.

In charge of CET/SBA, Santa

Casa de Misericórdia, Ribeirão Preto, SP 